\title{
Assessment of Use of Faculty Libraries Resources by Undergraduate Students in Benue State University Library Makurdi, Nigeria
}

\author{
Nancy Ngunan Ugbagir \\ University Library, Benue State University, Makurdi, Nigeria
}

Email address:

ngunanugbagir@gmail.com

\section{To cite this article:}

Nancy Ngunan Ugbagir. Assessment of Use of Faculty Libraries Resources by Undergraduate Students in Benue State University Library Makurdi, Nigeria. Humanities and Social Sciences. Vol. 4, No. 6, 2016, pp. 166-172. doi: 10.11648/j.hss.20160406.16

Received: October 18, 2016; Accepted: November 3, 2016; Published: December 12, 2016

\begin{abstract}
The study looks at assessment of use of faculty libraries resources by undergraduate students in Benue State University Library, Makurdi, Nigeria. The study adopted the descriptive survey design. The target population of the study was undergraduate students. The sample size of 361 from the population was drawn using Krejcie and Morgan sample size table; and simple random sampling technique was used in selecting the subjects for the study. Mean and standard deviation were used in answering the research questions for the study. It was discovered that lack of internet resources, lack of adequate reference materials, non-availability of reading tables and chairs, lack of necessary skills for internet use and power interruption, inadequate points of access in university faculty libraries and information centers were challenges hindering undergraduate students from using the faculty libraries resources for their learning and research. The study recommended that there should be provision of internet resources, acquisition of adequate reference materials, provision of reading tables and chairs, training of undergraduate students to acquire necessary skills for Internet use, provision of standby generators to manage power interruption and installation and provision of points of access in university faculty libraries and information centers.
\end{abstract}

Keywords: Faculty Libraries Resources, Undergraduate Students, Benue State University Library

\section{Introduction}

Academic libraries are increasingly been looked upon to document and articulate the value of academic and research resources in higher institutions of learning such as universities so as to contribute to the institutions' mission and goals. Gradually, academic library value has remained linked to service, rather than products aimed at user satisfaction. The academic library has been described as the "heart" of the learning community, providing a place for students and faculty to do their research and advance the frontiers of knowledge. The librarians and library staff provide numerous services to these users, addressing their diverse needs, characteristics, and interests. Essentially, in order to serve the community of users of the academic libraries, an advocacy of faculty libraries in universities became mandatory.

The core purpose of libraries as reservoirs of society's intellectual history and custodians of people's knowledge and information is to bring educational development and promote the peoples dwindling reading culture by making available, information materials for study or reference (Agber \& Mngutyô, 2013; Agber, Ugbagir, Mngutyô \& Amaakaven, 2014).

Libraries, irrespective of the type are meant to meet the information needs of their users. In University libraries, there are numerous library users including undergraduate students who need information for project writing. The students need information for their studies and research (Ani, 2005 \& Ugbagir, 2014).

Apparently, to create easy accessibility of library resources to library users in the universities, National Universities Commission of Nigeria established rules and regulations that faculty libraries should be established to decentralize university resources and sitting capacity. In order to abide by these rules and regulations, during the rule of Professor Akase Sorkar as the Vice Chancellor of Benue State University in the year 2006, five (5), more faculty libraries 
were established besides that of Faculty of Law and Health Sciences which are unique in nature. The aim and objectives of establishing faculty libraries was to equip them with specific library resources that tally with the programs offered in that faculty, as well as bringing the library closer to the faculty members. However, some undergraduate students seem to be complaining about lack of library information resources.

\section{Statement of the Problem}

Libraries, irrespective of the type are meant to meet the information needs of their users. In University libraries, there are numerous library users including undergraduate students who need information for different purposes. The students need information for their studies and research. The university library has established faculty libraries, which contain information resources ready for use by undergraduate students of the different faculties of the university.

Consequently, these faculty libraries are specifically stock with acquired and organized printed and electronic information sources for accessibility and use by undergraduate students. However, researchers attest that undergraduate students visit to university or faculty libraries for research seems to be frustrating. There also exists a poor level of use of the available information resources or materials, which are essential for learning and research. It is observed that undergrad students hardly use library resources for their learning and research and if not checked, the consequences in the future may be inconceivable. Therefore, this study seeks the reasons of hesitation of undergrad students at visiting library facility of the University for the achievement of their academic goals.

\subsection{Purpose of the Study}

The purpose of this study is to assess use of faculty libraries resources by undergraduate students in Benue State University, Makurdi, Nigeria. Specifically the study sought to:

1. find out the available library resources in faculty libraries in Benue State University

2. identify the challenges hindering undergraduate students from using the faculty libraries resources for their learning and research and

3. determine the strategies needed for the enhancement of usage of faculty libraries resources by undergraduate students

\subsection{Research Questions}

The following questions were asked to guide the study:

1. What are the available library resources in faculty libraries in Benue State University?

2. Are there challenges hindering undergraduate students from using the faculty libraries resources for their learning and research?

3. What are the strategies needed for the enhancement of usage of faculty libraries resources by undergraduate students?

\section{Literature Review}

\subsection{Benue State University, Makurdi}

Benue State University was established by the Benue State Government with the enactment of the Benue State University Edict No. 1 of 1991. The University took off in the 1992/93 academic year with four faculties, namely, Arts, Education, Science and Social Sciences. Two Faculties, Law and Management Sciences came on stream in the 1993/94 academic year. A post graduate school took off in the 1998/1999 academic year while the College of Health Sciences was established in the 2003/2004 academic session (Benue State University Makurdi, 2014).

\subsection{Brief History of Benue State University Library}

Benue State University, Makurdi was established in 1992, with Prof. Charles G. Vajime as the pioneer ViceChancellor and Dominic Gbakighir as the University Liberian (Akighir, 2008 \& Orbunde, 2011). Agber (2014) asserted that the university is located at the Bank of River Benue along Gboko Road. The University Library is situated at the first campus beside the Lawn Tennis Court, with the seating capacity of about 284 users at a time. The library has sub-divisions, which are the Faculty Liberians, Postgraduate, law library and the college of Health Sciences library.

The University Library took off in 1992 and the administration of the university Library on the initial stage centered on the established rules guiding the operations of the Library. By January 1993, the initial book stock was a paltry number of fifty (50) books received as donations to kick start the operations of the University Library. The staff strength stood at five to start the long journey to the present position. Essential and relevant items such as shelves, reading tables and chairs were added to enhance conducive reading environment, amongst other things (Ocheibi \& Abuul, 2012).

Apparently, by all indications, right from the inception, the University Library had a slow but steady development in material and human resources following the opening of reader services to users on 23rd August, 1993 in the first campus of the University to date (Agber, 2014).

\subsection{Benue State University Library Collections}

Statistics have revealed that from a humble collection of 50 books in 1993, the library has recorded a phenomenal growth in information resources, such as books and journals. By September 2012, the book stock has risen to 66,000 volumes. The library subscribes to over 500 current journals and 20,000 volumes of backsets, (Ocheibi \& Abuul, 2012; Agber, 2014). However, the figures seem to be so high though, this is not to suggest that they are falsified.

It is believed that the primary responsibility of the 
University Library is to support the University in areas of teaching and learning as well as research. Moreover, Ocheibi, Edem \& Anthony (2009) emphasized that to a large extent, the quality of a University product is measured by the services provided by the library.

Apparently, Agber (2014) agreed that the University library is at the forefront in the actualization of identified functions inter alia.

(a) Conservation of knowledge

(b) Pursuant, promotion and dissemination of knowledge through teaching

(c) Advancement of knowledge through research, pure and applied and development orientation

(d) Provision of intellectual leadership

\subsection{Benue State University Faculty Libraries}

Faculty libraries in Benue State University, Makurdi were established at different times as need arose. Essentially, Ugbagir (2015) noted that the present activities of faculty libraries started in January 2014 with 5 faculty and two departmental libraries including:

- Faculty of Education Library

- Faculty of Social Sciences Library

- Faculty of Science Library

- Faculty of Management Sciences Library and

- Faculty of Arts Library with two (2) departmental libraries:

- Mass Communication Department Library and

- Chemistry Department Library

Alumunku (2014) reported that the evolution of Mass Communication Department Library was in 2013 with past undergraduate projects and books. The sitting capacity was 32 with 400 projects between 2005 and 2012, 294 books and about 150 journals.

\subsection{Concept of Undergraduate Students}

The term undergraduate student is most commonly associated with a student in a college or university who has not yet received a degree. Bukky (2006), regarding the nature and category of students stated that the term undergraduate is used in this context as an adjective. Rajeev and Kaur (2006) stated that an undergraduate student is a person who studies, or is studying at a college, school or university. He should therefore be a person who is learning to fulfill his powers and to find ways of using them in the service of mankind.

From the research conducted by Glenda, Sonia, Dwayne, Phimore and Alleyne (2006) one can deduce that this concept embraces all undergraduate students irrespective of gender difference and faculties. Park and Snow (2009) asserted that an undergraduate student is someone who is studying in a higher institution or in a university for a first degree programme in any discipline.

Operational definition of undergraduate students for this study is students admitted in a college or university who are yet to receive a certificate of first degree for the completion of their course of study.

\subsection{Availability of Faculty Libraries Resources}

Library resources encompass so many things. It includes print materials such as books, journals, visuals and monographs among others; and non-print materials such as internet resources and audiovisuals.

Mitra and Steffensmmier (2000) noted that a networked learning institution where students have easy access to computers could foster positive attitudes towards the use of Internet resources in research. They found that Internetenriched research environment was positively correlated with students' attitudes towards computers in general, and the role of computers in facilitating research. The researcher noted that, inadequate computers, and low provision of bandwidth denies students access to Internet resources. Aguolu and Aguolu (2002) on their own part stressed that "availability" of learning resources means ensuring their presence in Nigerian universities for immediate use; this must be distinguished from their accessibility. Learning resources might be available but inaccessible to those who need them for whatever reasons. According to them, availability of learning materials should be viewed at both national and institutional levels. Accessibility of library resources may be conceptual, bibliographically identified and located. They further stated that the quality of learning materials acquired by universities whether as bibliographical resources, technological devices or instructional aides depend very largely upon the quality of decisions made by librarians and faculty members in selecting specific titles for acquisition, whether through purchase, exchange or gift. Ajai and Akinniyi (2004), Okiy (2005), found frustration among information seekers due to non-availability of library resources. The libraries ought to collect resources such as journals, books, reference materials, audiovisual materials, theses or dissertations, electronic resources such as ejournals, e-books and databases among others.

According to Kanamadi and Kumbar (2007), the nature, and efficiency of information services provided by university depends upon the computer facilities it has. If the university lacks computer infrastructure (the basic systems and services that are necessary for a country or an organization to run smoothly), then there is every possibility that it fails miserably to meet the demands of users. In the recent decades, much information has been made available in a wide variety of formats like CD-ROM, online databases and e-journals.

Sahin, Balta and Ercan (2010) agreed that the most effective communication resources, computers and the Internet, are part of our daily life and have become one of the important tools in the education. The Internet helps transfer information between different points therefore this satiation makes the Internet a very powerful information system. People in different age groups and jobs, students and academicians who do scientific research and prepare projects prefer using the Internet because it is the easiest, fastest, and cheapest ways of accessing necessary information. Methods of using academic resources, especially the ability to scan the 
articles for information is very important for academic research. The similarities and differences between articles on the same subject can be used to classify them for literature review. Grouping of the articles in detail helps keep the expected originality of the text in order to complete the project successfully. They therefore, identified the available Internet resources such as academic e-journals, search engines, blogs, forums, distant learning and related software.

\subsection{Challenges of Use of Faculty Libraries Resources}

There are numerous challenges of using faculty libraries resources such as lack of internet resources, lack of adequate reference materials, reading tables and chairs. Internet resources used is not adequate, Internet services are not adequate, lack of necessary skills for Internet use, power interruption and lack of straightforwardness of Internet resources. Ojedokun (2001), Luambano and Nawe (2004), Ojobah and Asaolu (2005) asserted that undergraduate students face challenges of inadequacy of computers and other resources such as e-journals, e-books, bandwidth, inadequate points of access in libraries and information centers. Barberio (2004) who reported that most undergraduate students lack the knowledge of surfing the web as such; they could not find the needed information on the web.

\subsection{Strategies Needed for Enhancement of Use of Faculty Libraries Resources}

Apparently, strategies are needed for enhancement of use of faculty libraries resources by undergraduate students such as subscription of higher bandwidth, provision of more computers, introduction of user education and the improvement of power supply through provision of standby generators and inverters and organizing of Internet materials.

Kaniki (1996) noted that there must be a proper Internet user education programme throughout the first degree programme. This could be integrated into the school, academic curriculum and taught by both librarians and faculty - members. This teaching should be carried out in a well - equipped networked room. In the process of teaching and learning, task should be set to find out skills that are not as comprehensive as one would be led to believe.

Concerning the inadequacy of computer and Internet facilities such as bandwidth, Association of African Universities (2000) suggested that Nigerian University Libraries should be well funded, and allowed to purchase computers for undergraduate students use for their research project. Also subscription for higher bandwidth will determine the higher flow of information from the Internet to computers. This will also solve the problem of slowness of the system.

Moreover, on electrical power source, besides the pronouncement by Nigeria's President on National Electrical Power Authority - NEPA (now Power Holding Company of Nigeria - PHCN) uninterrupted power supply in December 2001, Okoro (2005) noted that the idea was a welcome development; services are more efficient than what was before. However, there is need for the government to take more stringent measures to achieve this laudable venture. However, the researcher noted that besides the Nigerian government efforts on provision of power supply, the university libraries should be provided with standby generators so that, at any time power supply is interrupted, it may be put into use immediately in order to help the computers working while the researchers continue with their Internet research.

\section{Methodology}

The study adopted a descriptive survey design. The design is considered appropriate because it allows the researcher to make inferences and generalization of the population by selecting and studying the sample of the study. It is used to critically analyze the situation based on information, (Nworgu, 2006).

\subsection{Population and Sample}

The target population of this study was undergraduate students from Faculties of Education, Social Sciences, Science, Management Sciences and Arts as well as departments of Mass Communication and Chemistry who were users in Benue State University Faculty Libraries. There are about 6,304 users (Ugbagir, 2015). A sample of 361 was therefore, drawn using Krejcie and Morgan sample size table (Krejcie \& Morgan, 1970, Emaikwu, 2015). A simple random sampling technique was used in selecting the sample of the study. The simple random sampling technique of hat and draw was used where the researcher wrote numbers on pieces of papers representing respondents. The pieces of papers were wrapped and put in a container, reshuffled properly and drawn. The drawn numbers corresponding to respondents were then selected so as to ensure equal chances for all respondents to be selected.

\subsection{Instrument for Data Collection}

The instrument used for data collection was the Assessment of Faculty Library Resources Questionnaire (AFLRQ) constructed by the researcher. Section A of the questionnaire was on bio-data of the respondents covering sex. Section B consisted of 9 variables of Available Library Resources in Faculty Libraries in Benue State University. Section C consisted of 6 variables of Challenges of Use of Faculty Libraries Resources and Section D consisted of 6 variables of Strategies Need for Enhancement of Use of Faculty Libraries Resources. The 21 item questionnaire adapted a 4-point rating scale and respondents were asked to respond by ticking the applicable responses (SA) strongly agree, (A) agree, (D) disagree and (SD) strongly disagree. The analysis used mean and standard deviation. Any item of the instrument whose mean rating scores was 2.50 and above was 
considered significant and any item less than 2.50 was considered not significant.

The questionnaires were administered to the respondents in the study area and were retrieved from the respondents by the researcher and two (2) research assistants. The questionnaires were administered and retrieved through personal contact.

\subsection{Answers to Research Question}

The data for this research were collected using 4-point rating scale instrument and on each of the research questions, data were collected on related items in the instrument. Consequently, the data collected were analyzed using mean and standard deviation. Items of the instrument with mean rating scores of 2.50 and above were deemed significant and items with less were not considered significant.

\subsection{Demographic Information}

Demographically, data were collected from 361 Faculty Library Users in University Library and Information Services of the Benue State University, Makurdi out of which 108 were male representing $29.9 \%$ while 253 representing $70.1 \%$ were female.

\subsection{Research Question 1}

What are the available library resources in faculty libraries in Benue State University?

In order to answer the research question, data were collected on the available library resources in faculty libraries in Benue State University, Makurdi. The collected data were analyzed and presented in Table 1 .

Table 1. Descriptive Statistics of Available Library Resources in Faculty Libraries in Benue State University.

\begin{tabular}{llll}
\hline Descriptive Statistics & & & \\
\hline & N & Mean & Std. Deviation \\
\hline Journals & 361 & 2.6260 & 1.26108 \\
Books & 361 & 3.0055 & 1.18085 \\
Reference Materials & 361 & 2.6039 & 1.28274 \\
Audiovisual Materials & 361 & 2.6011 & .62928 \\
Theses & 361 & 2.5900 & 1.41158 \\
Dissertations & 361 & 2.7784 & .97791 \\
E-journals & 361 & 2.6011 & 1.03623 \\
E-books & 361 & 2.9723 & 1.31627 \\
Databases & 361 & 2.8033 & 1.03150 \\
Cluster Mean of Available Library Resources in Faculty Libraries in Benue State University & 361 & 2.7313 & .76555 \\
Valid N (listwise) & 361 & & \\
\hline
\end{tabular}

From Table 1, it can be seen that the mean score of all the items is above 2.50 with the cluster mean of 2.73 , which implies that journals, books, reference materials, audiovisual materials, theses, dissertations, e-journals, e-books and databases are the available library resources in faculty libraries in Benue State University, Makurdi.

\subsection{Research Question 2}

Are there challenges hindering undergraduate students from using the faculty libraries resources for their learning and research?

In order to answer the research question, data were collected on challenges hindering undergraduate students from using the faculty library resources for their learning and research. The collected data were analyzed and presented in Table 2 .

Table 2. Descriptive Statistics of Challenges of Use of Faculty Libraries Resources.

\begin{tabular}{|c|c|c|c|}
\hline \multicolumn{4}{|l|}{ Descriptive Statistics } \\
\hline & $\mathbf{N}$ & Mean & Std. Deviation \\
\hline Lack of internet resources & 361 & 2.8006 & 1.34953 \\
\hline lack of adequate reference materials & 361 & 3.0000 & 1.00000 \\
\hline Non-availability of reading tables and chairs & 361 & 2.5429 & 1.33498 \\
\hline Lack of necessary skills for Internet use & 361 & 2.6620 & 1.34657 \\
\hline Power interruption & 361 & 2.5734 & 1.25200 \\
\hline Inadequate points of access in university faculty libraries and information centers & 361 & 2.6620 & .85109 \\
\hline Cluster Mean of Challenges of Use of Faculty Libraries Resources & 361 & 2.7068 & .96377 \\
\hline Valid N (listwise) & 361 & & \\
\hline
\end{tabular}

From Table 2, it can also be seen that the mean scores of all the items is above 2.50, with the cluster mean of 2.70 . This implies that lack of internet resources, lack of adequate reference materials, non-availability of reading tables and chairs, lack of necessary skills for internet use and power interruption, inadequate points of access in university faculty libraries and information centers are the challenges hindering undergraduate students from using the faculty libraries resources for their learning and research. 


\subsection{Research Question 3}

What are the strategies needed for the enhancement of usage of faculty libraries resources by undergraduate students?
In order to answer the research question, data were collected on strategies needed for the enhancement of usage of faculty library resources by undergraduate students. The collected data were analyzed and presented in Table 3.

Table 3. Descriptive Statistics of Strategies Needed for Enhancement of Use of Faculty Libraries Resources.

\begin{tabular}{|c|c|c|c|}
\hline \multicolumn{4}{|l|}{ Descriptive Statistics } \\
\hline & $\mathbf{N}$ & Mean & Std. Deviation \\
\hline Provision of internet resources & 361 & 2.7950 & 1.32165 \\
\hline Acquisition of adequate reference materials & 361 & 2.6150 & 1.15888 \\
\hline Provision of reading tables and chairs & 361 & 2.5291 & 1.17845 \\
\hline Training of undergraduate students to acquire necessary skills for Internet use & 361 & 2.9169 & 1.31604 \\
\hline Provision of standby generators to manage power interruption & 361 & 2.9169 & 1.06915 \\
\hline Installation and provision of points of access in university faculty libraries and information centers & 361 & 2.7507 & 1.30124 \\
\hline Cluster Mean of Strategies Needed for Enhancement of Use of Faculty Libraries Resources & 361 & 2.7539 & .94559 \\
\hline Valid N (listwise) & 361 & & \\
\hline
\end{tabular}

From Table 3, it can be seen that the mean scores of all the items is above 2.50 , with the cluster mean of 2.75 . This implies that provision of internet resources, acquisition of adequate reference materials, provision of reading tables and chairs, training of undergraduate students to acquire necessary skills for Internet use, provision of standby generators to manage power interruption and installation and provision of points of access in university faculty libraries and information centers are the strategies needed for the enhancement of usage of faculty libraries resources by undergraduate students.

\section{Discussion of Findings}

1. Based on the results in Table 1, the findings from the study revealed that journals, books, reference materials, audiovisual materials, theses, dissertations, e-journals, ebooks and databases are the library resources available in faculty libraries in Benue State University, Makurdi. This is in line with Kanamadi and Kumbar (2007), who noted that in the recent decades, much library resources has been made available in a wide variety of formats like CD-ROM, online databases and e-journals.

2. Based on the results in Table 2, the study revealed that lack of internet resources, lack of adequate reference materials, non-availability of reading tables and chairs, lack of necessary skills for internet use and power interruption, inadequate points of access in university faculty libraries and information centers are the challenges hindering undergraduate students from using the faculty libraries resources for their learning and research. Apparently, this is in agreement with Ojedokun (2001), Luambano and Nawe (2004), Ojobah and Asaolu (2005) who asserted that undergraduate students face challenges of inadequacy of computers and other resources such as e-journals, e-books, bandwidth, inadequate points of access in libraries and information centers.

3. Based on the results in Table 3 , the study revealed that provision of internet resources, acquisition of adequate reference materials, provision of reading tables and chairs, training of undergraduate students to acquire necessary skills for Internet use, provision of standby generators to manage power interruption and installation and provision of points of access in university faculty libraries and information centers are the strategies needed for the enhancement of usage of faculty libraries resources by undergraduate students. This is partly in line with Association of African Universities (2000) when it suggested that Nigerian University Libraries should be well funded and allowed to purchase computers for undergraduate students use for their research and that subscription for higher bandwidth will determine the higher flow of information from the Internet to computers.

\section{Conclusion}

University library is a potential entity in the process of teaching and learning anywhere in the world but for users to find it useful, the library resources must be available and accessible for utilization. Nevertheless, if library resources are available and accessible but are not utilized, it then entails that something is wrong. This study concluded that the challenges that hinder undergraduate students from using the faculty libraries resources for their learning and research can be eradicated by imparting knowledge on necessary skills not only for Internet use but also for general good use of other library resources into the undergraduate students.

\section{Recommendations}

The research finding discovered that faculty library resources are available in faculty libraries in Benue State University, Makurdi. However, there are challenges hindering undergraduate students from using the faculty libraries resources for their learning and research. It was therefore, recommended that there should be provision of internet resources, acquisition of adequate reference materials, provision of reading tables and chairs, training of undergraduate students to acquire necessary skills for Internet use, provision of standby generators to manage power interruption and installation and provision of points of access in university faculty libraries and information centers. 


\section{References}

[1] Agber, T. C. \& Mngutyô, J. N. (2013). Library's Role in Preservation of Tiv Traditional Music in Benue State. Benue Journal of Library, Management and Information Science, 3 (2), 65-79.

[2] Agber, T. C., Ugbagir, N. N. Mngutyô, J. N. \& Amaakaven, F. G. (2014). Acquisition of audiovisual materials on the Tiv Tyumbun Magic Rite by the public libraries in Benue state of Nigeria. LIBRI, 64 (4), 408-419.

[3] Agber, T. C. (2014). Practical experience on industrial training in Benue State University Library (Unpublished DLS Report). Benue State University, Makurdi.

[4] Alumunku, P. (2014). Evolution of Mass Communication Department Library of the Benue State University, Makurdi (Unpublished library report). Benue State University, Makurdi.

[5] Ani, O. E. (2005). Evolution of Virtual Libraries in Nigeria: Myth or reality. Journal of Information Science, 31 (1), 67-70.

[6] Association of African Universities (2000). Technical Experts Meeting on the Use and Application of Information and Communication Technologies in Higher Education Institutions in Africa, $7^{\text {th }}-19^{\text {th }}$, May. University of Dares Salaam, Tanzania.

[7] Barberio, R. P. (2004). The One-Armed Bandit Syndrome : Overuse of the internet in Students Research Project. Political Science of Politics, 37 (2), 307-311.

[8] Bukky, O. O. (2006). A Survey of Internet Access and Usage Among Undergraduate in an African University. Retrieved from

$\mathrm{http} /$ www.infor.sciencedirectinternationalinformation\&library review. 2/22/2009.

[9] Glenda, G. A, Sonia, M. D, Wayne, D. P, Hilmore, A. \& Peter, G. A. (2006). Perception of Information and Communication Technology Among Undergraduate Management Students in Barbados. International Journal of Education and Development Using ICT, 2 (4), 223-247.

[10] Kanamadi, S. \& Kumbar, B. D. (2007). Impact of Information Technology Innovation on Resources and Services of Management Institute Libraries in Mumbai: A Librarians' Approach. Electronic Journal of Academic and Special Librarianship, 8 (1), 1-9.
[11] Kaniki, A. M (1996). Virtual, Digital Libraries: Wither South African Academic Libraries?. Conference on Information Technology in Tertiary Education, $10-12^{\text {th }}$ April. Cape Town, University of Cape Town.

[12] Krejcie, R. V. \& Morgan, D. W. (1970). Determining sample size for research activities. Educational and Psychological Measurement, 30, 607-610.

[13] Luambano, I. \& Nawe, J. (2004). Internet Use by Students of University of Dares Salaam. Library Hi Tech News, 20 (10), 13-17.

[14] Noworgu, B. G. (2006). Introduction to educational research. Ibadan: Longman Nigeria Publishers.

[15] Ocheibi, J. A. \& Abuul, T. (2012). The university ICT and library development in Benue state university. In O. Ajene, M. A. Adejo, \& M. George-Genyi, (Eds.). Benue state university at 20: achievements, challenges \& prospects. Makurdi: Benue State University Press

[16] Ojedokun, A. A (2001). Internet Access and Usage by Students of University of Botswana. African Journal of Library, Archives and Information Science, 14 (2), 97-107.

[17] Ojobah, B. A. and Asaolu, M. F. (2005). Studies on Internet Access and Usage by Students of the Federal University of Technology, Akure, Nigeria. African Journal of Library Archives and Information, 15 (2), 117-124.

[18] Okoro, A. M. (2005). The Challenges of Information Communication Technologies (ICT) for Nigerian Academic Libraries. Global Review of Library and Information Science, $1(1), 88-89$.

[19] Orbunde, M. C. (2011). Report on practical experience on industrial training attachment (Unpublished DLS Report). Benue State University, Makurdi.

[20] Rajeev, K \& Kaur, A. (2006). Internet Use by Teachers and Students in Engineering Colleges of Punjab, Haryana and Himachal Pradesh States of India: An Analysis. Electronic Journal of Academic and Special Librarianship.

[21] Ugbagir, N. N. (2014). Undergraduate students' use of internet resources for research projects in universities in North-Central Nigeria (Unpublished $\mathrm{PhD}$ Dissertation). University of Nigeria, Nsukka.

[22] Ugbagir, N. N. (2015). Report of faculty libraries of Benue State University, Makurdi (Unpublished Faculty Libraries Report). Benue State University, Makurdi. 